\title{
Formulasi dan Karakterisasi Sediaan Nanoemulgel Serbuk Lidah Buaya (Aloe Vera L.)
}

\section{Formulation and Characterization of Nanoemulgel Containing Aloe Vera L. Powder}

\author{
Teguh Imanto*, Roseh Prasetiawan, Erindyah Retno Wikantyasning \\ Fakultas Farmasi, Universitas Muhammadiyah Surakarta, Jl. A. Yani Tromol Pos 1 Pabelan, \\ Kartasura, Sukoharjo, 57162, Indonesia \\ *E-mail: teguh.imanto@ums.ac.id
}

\begin{abstract}
Abstrak
Lidah buaya (Aloe vera L.) mengandung zat saponin yang bersifat antiseptik dan komplek antrakuinon sebagai senyawa antibakteri. Penelitian ini dilakukan untuk memformulasikan serbuk lidah buaya menjadi sediaan nanoemulgel, melakukan karakterisasi dan uji sifat fisiknya, serta untuk mengetahui pengaruh konsentrasi gelling agent (karbopol dan kitosan) terhadap sediaan nanoemulgel. Tipe emulsi yang digunakan yaitu minyak dalam air $(\mathrm{O} / \mathrm{W})$ dengan surfaktan tween 80 dan ko-surfaktan propilenglikol. Nanoemulsi dikarakterisasi persen transmittan dengan spektrofotometer UV-Vis, serta distribusi ukuran droplet dan zeta potensial dengan Particle Size Analyzer. Hidrogel terdiri dari 4 formula kombinasi karbopol 0,5\%; 1\%; 1,5\%; 2\% dan kitosan $0,3 \%$. Formula diuji sifat fisik yang meliputi organoleptis, $\mathrm{pH}$, daya sebar, daya lekat, viskositas dan stabilitas dengan metode freeze thaw. Hasil penelitian menunjukan ukuran droplet nanoemulsi adalah $65,05 \mathrm{~nm} \pm 13,49$ dengan zeta potensial sebesar $-0,1 \mathrm{mV}$ serta persen transmittan diatas $98 \%$. Hasil uji sifat fisik keempat formula menunjukkan adanya perbedaan konsentrasi gelling agent memberikan perbedaan sifat fisik viskositas dan daya sebar. Secara keseluruhan formula 3 memiliki sifat fisik dan stabilitas fisik yang paling baik dibandingkan formula 1, 2 dan 4.
\end{abstract}

Kata Kunci: Aloe vera L., lidah buaya, nanoemulgel, karbopol, kitosan

\begin{abstract}
Aloe vera L. contains antiseptic saponins and anthraquinone complexes as antibacterial. This research was conducted to formulate aloe vera powder into nanoemulgel, characterize and test its physical properties, and to know the effect of gelling agent concentration (carbopol and chitosan) on nanoemulgel. Emulsion type used is oil in water $(O / W)$ with surfactant tween 80 and co-surfactant propylene glycol. Nanoemulsion is characterized by percent of transmittance with UV-Vis spectrophotometer, also potential droplet and zeta size distribution with Particle Size Analyzer. Hydrogels consist of 4 combination formulas of carbopol 0.5\%; 1\%; $1.5 \%$; $2 \%$ and $0.3 \%$ chitosan. The formula is tested for physical properties including organoleptic, pH, spreadability, adhesion, viscosity and stability with freeze thaw method. The results showed that the nanoemulsion droplet size was $65.05 \mathrm{~nm} \pm 13.49$ with zeta potential of $-0.1 \mathrm{mV}$ and the percent of transmittance above $98 \%$. The result of physical properties of the four formulas shows that the different gelling agent concentration gives different physical properties of viscosity and spreadability. Overall, formula 3 has the best physical properties and physical stability compared to formula 1, 2 and 4.
\end{abstract}

Keywords: Aloe vera L., aloe vera, nanoemulgel, carbopol, chitosan

\section{PENDAHULUAN}

Lidah buaya (Aloe vera L.) mempunyai aktivitas antijamur, antivirus dan antibakteri terhadap beberapa infeksi kulit seperti herpes, luka bakar dan jerawat (Bashir et al., 2011). Lidah buaya mengandung zat saponin yang bersifat antiseptik dan komplek antrakuinon (aloe emodin, aloin, barbaloin) sebagai senyawa antibakteri (Furnawanthi, 2002). Senyawa antibakteri dalam lidah buaya dapat digunakan untuk pengobatan infeksi luka bakar. Infeksi luka bakar disebabkan oleh bakteri aerob seperti Pseudomonas aeruginosa (Christiawan and Perdanakusuma, 2010). Dalam penelitian Al-Fatimi et al. (2007) serbuk lidah buaya dengan metode 
freeze drying mampu menghambat pertumbuhan dari bakteri Pseudomonas aeruginosa.

Penelitian perbandingan lidah buaya terhadap beberapa standar antibiotik (metisilin, basitrasin, novobiosin dan eritomisin) menunjukkan bahwa gel lidah buaya efektif terhadap bakteri gram positif sebesar $75,3 \%$ dari bakteri yang diisolasi meliputi Staphylococcus aureus, Staphylococcus epidermidis, Streptococcus pyogenes dan bakteri gram negatif sebesar $100 \%$ dari bakteri yang diisolasi meliputi Pseudomonas aeruginosa (Bashir et al., 2011). Singh et al. (2012) menyatakan bahwa penghantaran obat dipengaruhi oleh besar kecilnya ukuran partikel, karena adanya barier membran kulit. Semakin kecil ukuran partikel maka akan semakin mudah untuk menembus barier membran kulit dan semakin baik efeknya. Salah satu sediaannya yaitu nanoemulgel. Nanoemulgel merupakan suatu sediaan emulsi dengan ukuran droplet 1-100 $\mathrm{nm}$ yang disuspensikan dalam suatu hidrogel. Komponen minyak, surfaktan dan kosurfaktan dapat meningkatkan penetrasi zat aktif sehingga akan meningkatkan efektifitas terapi. Dalam penelitian Arellano et al. (1999), kombinasi propilenglikol dan isopropilmiristat berperan secara sinergis meningkatkan penetrasi melalui membran kulit. Gel karbopol yang mengandung propilenglikol dan isopropilmiristat memberikan efek peningkatan yang baik.

Penggunaan kitosan sebagai gelling agent dan kolagen sebagai bahan tambahan pada nanoemulgel dapat meningkatkan efektifitas zat aktif. Kitosan tersedia dalam berbagai bentuk yang berguna, menampilkan sifat yang menarik seperti biokompatibilitas atau biodegradabilitas (Kumar et al., 2004) dan produk degradasinya tidak beracun, tidak bersifat imunogenik dan non-karsinogenik. Kitosan digunakan secara luas dalam berbagai aplikasi seperti imobilisasi enzim, sebagai mediator penyembuhan luka, dalam aplikasi gigi, sebagai perban adesi untuk operasi dan pada sistem penghantaran obat (Prabaharan and Mano, 2005). Kolagen merupakan komponen yang dapat meningkatkan regenerasi kulit yang baik untuk sediaan emulgel (Widayanti et al., 2016).

Penelitian ini bertujuan untuk memformulasikan serbuk lidah buaya dalam sediaan nanoemulgel dengan menggunakan kombinasi kitosan-karbopol 940 sebagai gelling agent dan untuk mengetahui pengaruh konsentrasi gelling agent terhadap sifat fisik sediaan dan stabilitas fisik sediaan. Nanoemulgel serbuk lidah buaya diharapkan dapat meningkatkan efektifitas terapi yang dihasilkan.

\section{METODE PENELITIAN \\ Alat}

Alat yang digunakan dalam penelitian ini yaitu neraca analitik (Ohaus-Jerman), Freeze dryer (Christ Alpha 1-2 LO plus), Particle Size Analyzer (PSA) (HORIBA SZ-100), alat uji daya lekat, alat uji daya sebar, viskosimeter RION (Viskotester VT-06E), spektrofotometer UV-Vis (Genesys 10S UVVIS), inkubator (Memmert), stirrer (Thermo Scientific Cimarec), magnetic stirrer (Thermo Scientific Cimarec), lemari pendingin (Polytron), pH stick (Suncare universal test paper), alat gelas (Pyrex), mortir dan stemper, blender (Miyako).

\section{Bahan}

Bahan-bahan yang digunakan adalah lidah buaya yang didapat dari penjual tanaman di Surakarta, etanol 96\% (teknis), asam asetat (pa), isopropil miristat (teknis, Brataco), tween 80 (teknis, Brataco), propilenglikol (teknis, Brataco), karbopol 940, trietanolamin (teknis), metilparaben, kitosan (Bio Chitosan Indonesia), kolagen (Fish Collagen-Bio Chitosan Indonesia), akuades, akua proinjeksi (Ikapharmindo).

\section{Pembuatan Serbuk Kering Lidah Buaya}

Pembuatan serbuk kering lidah buaya menggunakan metode freeze drying untuk menghilangkan kandungan air di dalam lidah buaya. Daun lidah buaya segar dikupas dan dicuci kemudian di blender dan ditimbang untuk didapatkan berat basah. Lidah buaya 
yang telah diblender, dimasukkan dalam beberapa wadah yang kemudian didiamkan selama 24 jam pada almari pembeku. Lidah buaya beku kemudian dimasukkan pada freeze dryer pada suhu $-50^{\circ} \mathrm{C}$ dengan tekanan 0,12 mbar selama 24 jam. Hasil yang didapat kemudian ditimbang dan didapatkan berat kering.

\section{Formulasi Nanoemulsi}

Formula nanoemulsi yang dibuat dapat dilihat pada tabel 1 dan formula gel nanoemulsi dapat dilihat pada tabel 2 .

Tabel 1. Formula nanoemulsi serbuk lidah
\begin{tabular}{lr}
\multicolumn{2}{c}{ buaya } \\
\hline Bahan & Formula \\
\hline Serbuk lidah buaya & $500 \mathrm{mg}$ \\
Isopropilmiristat & $5 \mathrm{~mL}$ \\
Tween 80 & $22,5 \mathrm{~mL}$ \\
Propilenglikol & $22,5 \mathrm{~mL}$ \\
Kolagen & $3 \mathrm{~g}$ \\
Akua p.i & $50 \mathrm{~mL}$ \\
\hline
\end{tabular}

Pembuatan nanoemulsi membutuhkan bahan serbuk kering lidah buaya (zat aktif), isopropilmiristat (minyak), tween 80 (surfaktan), propilenglikol (kosurfaktan) serta kolagen sebagai bahan tambahan pada fase air (akua p.i).Pembuatan nanoemulsi dilakukan dengan melarutkan serbuk terlebih dahulu dalam $10 \mathrm{~mL}$ akua p.i dengan bantuan stirer sampai larut, serta dibuat fase air dengan melarutkan kolagen pada sisa akua p.i $(40 \mathrm{~mL})$ dengan bantuan stirer sampai larut sempurna. Serbuk yang sudah larut kemudian dimasukkan tetes demi tetes ke dalam propilenglikol sambil diaduk menggunakan stirer pada kecepatan 10 selama 5 menit dengan suhu dijaga $75^{\circ} \mathrm{C}$. Kemudian ditambahkan tween 80 sedikit demi sedikit dengan tetap diaduk pada kecepatan 10 selama 5 menit dengan suhu $75^{\circ} \mathrm{C}$ untuk menghomogenkan campuran. Selanjutnya, ditambahkan isopropilmiristat (minyak) tetes demi tetes ke dalam campuran dengan tetap diaduk pada kecepatan 10 dengan suhu $75^{\circ} \mathrm{C}$ selama 5 menit. Dimasukkan fase air tetes demi tetes ke dalam campuran dengan tetap memperhatikan putaran dan suhu stirer. Hasil nanoemulsi kemudian dimasukkan ke dalam botol dan didiamkan selama 24 jam untuk mendapat hasil yang jernih.

\section{Formulasi Nanoemulgel}

Pembuatan gel nanoemulsi dilakukan dengan mengembangkan terlebih dahulu karbopol 940 dalam akuades panas $(10 \mathrm{~mL})$ selama 24 jam, serta melarutkan kitosan dalam asam asetat $1 \%(10 \mathrm{~mL})$. Kitosan yang sudah larut dibasakan terlebih dahulu dengan $\mathrm{NaOH}$ $0,1 \mathrm{~N}$ sebanyak $10 \mathrm{~mL}$ (sampai $\mathrm{pH}$ 5). Karbopol yang sudah mengembang dipindahkan sedikit ke dalam mortir dan ditambahkan metilparaben yang sudah dilarutkan dalam etanol 96\%, diaduk sampai homogen. Ditambahkan trietanolamin dan diaduk sampai homogen. Dituangkan sedikit demi sedikit nanoemulsi dan karbopol yang tersisa sambil tetap diaduk sampai terbentuk massa gel yang homogen. Selanjutnya,

Tabel 2. Formula gel nanoemulsi serbuk lidah buaya

\begin{tabular}{lllll}
\hline \multirow{2}{*}{ Bahan } & \multicolumn{4}{c}{ Formula } \\
\cline { 2 - 5 } & F1 & F2 & F3 & F4 \\
\hline Karbopol 940 & $0,50 \mathrm{~g}$ & $1,00 \mathrm{~g}$ & $1,50 \mathrm{~g}$ & $2,00 \mathrm{~g}$ \\
Kitosan & $0,30 \mathrm{~g}$ & $0,30 \mathrm{~g}$ & $0,30 \mathrm{~g}$ & $0,30 \mathrm{~g}$ \\
Asam Asetat $1 \%$ & $10,0 \mathrm{~mL}$ & $10,0 \mathrm{~mL}$ & $10,0 \mathrm{~mL}$ & $10,0 \mathrm{~mL}$ \\
Akuades & $10,0 \mathrm{~mL}$ & $10,0 \mathrm{~mL}$ & $10,0 \mathrm{~mL}$ & $10,0 \mathrm{~mL}$ \\
Trietanolamin & $0,60 \mathrm{~g}$ & $0,60 \mathrm{~g}$ & $0,60 \mathrm{~g}$ & $0,60 \mathrm{~g}$ \\
Etanol 96\% & $5,00 \mathrm{~mL}$ & $5,00 \mathrm{~mL}$ & $5,00 \mathrm{~mL}$ & $5,00 \mathrm{~mL}$ \\
Metilparaben & $0,20 \mathrm{~g}$ & $0,20 \mathrm{~g}$ & $0,20 \mathrm{~g}$ & $0,20 \mathrm{~g}$ \\
NaOH 0,1 N & $10,0 \mathrm{~mL}$ & $10,0 \mathrm{~mL}$ & $10,0 \mathrm{~mL}$ & $10,0 \mathrm{~mL}$ \\
Nanoemulsi & $74,4 \mathrm{~mL}$ & $74,4 \mathrm{~mL}$ & $74,4 \mathrm{~mL}$ & $74,4 \mathrm{~mL}$ \\
\hline
\end{tabular}


ditambahkan kitosan sedikit demi sedikit sambil tetap diaduk sampai terbentuk massa gel yang homogen.

\section{Uji Sifat Fisik Sediaan}

Evaluasi sediaan fisik nanoemulgel serbuk lidah buaya meliputi uji karakterisasi nanoemulsi, uji pengamatan organoleptis gel, $\mathrm{pH}$, viskositas, daya lekat, daya sebar, dan stabilitas metode freeze thaw.

\section{a. Karakterisasi nanoemulsi}

Karakterisasi nanoemulsi dilakukan dengan parameter nilai persen transmittan, ukuran droplet dan nilai zeta potensial. Nilai transmittan diukur dengan menggunakan spektrofotometer UV-Vis pada panjang gelombang $650 \mathrm{~nm}$ dengan blanko akuades. Ukuran droplet dan zeta potensial nanoemulsi dilakukan dengan menggunakan alat Particle Size Analyzer (PSA-HORIBA SZ-100), dengan metode dynamic light scattering dengan sudut scattering $90^{\circ}$.

\section{b. Organoleptis nanoemulgel}

Sediaan nanoemulgel serbuk lidah buaya yang telah dibuat diamati secara fisik meliputi warna, bau, homogenitas, konsistensi.

\section{c. Uji pH}

Pengukuran $\mathrm{pH}$ sediaan nanoemulgel serbuk lidah buaya menggunakan universal pH stick. Pengukuran dilakukan 3 kali.

\section{d. Uji viskositas}

Pengukuran viskositas nanoemulgel menggunakan viskosimeter RION rotor no 1 dan rotor no 2. Sampel gel dimasukan ke dalam pot yang akan di uji. Rotor ditempatkan ditengah-tengah pot yang sudah berisi sampel gel nanoemulsi, kemudian alat dihidupkan. Angka yang didapatkan akan muncul pada layar, setelah stabil kemudian dibaca skala yang ada pada viskosimeter tersebut. Dilakukan 3 kali pengukuran.

\section{e. Uji daya lekat}

Sebanyak 0,25 gram nanoemulgel diletakkan di atas object glass dan ditempelkan pada object glass yang lain lalu ditekan dengan beban $1 \mathrm{~kg}$ selama 5 menit. Object glass dipasang pada alat tes dan dilepaskan beban seberat 80 gram. Dicatat waktu yang dibutuhkan hingga object glass terlepas. Dilakukan 3 kali pengujian.

\section{f. Uji daya sebar}

Sediaan nanoemulgel ditimbang 0,5 gram dan diletakkan pada bagian tengah cawan petri pertama yang telah diberi millimeter blok. Cawan petri kedua diletakkan di atas cawan petri pertama sebagai beban awal selama 1 menit. Diukur diameter penyebaran gel pada 4 sisi cawan pteri. Diulang pengukuran daya sebar geldengan penambahan beban 50 gram tiap 1 menit sampai beban yang diberikan sebesar 300 gram. Pengujian dilakukan 3 kali.

\section{g. Uji stabilitas fisik metode freeze thaw}

Pengujian stabilitas dengan metode freeze thaw sebanyak 6 siklus. Tiap siklus terdiri dari penyimpanan sediaan pada suhu $4^{\circ} \pm 2^{\circ} \mathrm{C}$ selama 24 jam lalu dilanjutkan pada suhu $40^{\circ} \mathrm{C} \pm 2^{\circ} \mathrm{C}$ untuk 24 jam berikutnya $(1$ siklus). Pengamatan dilakukan terhadap organoleptis, $\mathrm{pH}$, daya sebar, daya lekat dan viskositas (Elya et al., 2013).

\section{Analisa Data}

Data hasil sifat fisik sediaan nanoemulgel meliputi viskositas, daya lekat dan daya sebar gel dianalisa secara statistik menggunakan uji ANOVA satu jalan dengan taraf kepercayaan $95 \%$.

\section{HASIL DAN PEMBAHASAN}

Serbuk kering lidah buaya dibuat dengan metode freeze drying. Metode ini digunakan untuk mencegah terjadinya degradasi senyawa yang terkandung di dalam lidah buaya dengan menggunakan suhu pengeringan yang rendah. Serbuk kering lidah buaya yang didapat mempunyai organoleptis warna hijau pucat, bentuk serabut seperti kapas dan bau khas lidah buaya. Freeze drying dari 535,54 gram daun lidah buaya segar menghasilkan serbuk kering sebanyak 9,71 gram sehingga meghasilkan rendemen sebesar $1,81 \%$.

Formula 1, formula 2, formula 3 dan formula 4 pada gambar 1(a) merupakan formula sediaan nanoemulsi serbuk lidah buaya yang sama. Hasil formulasi nanoemulsi 


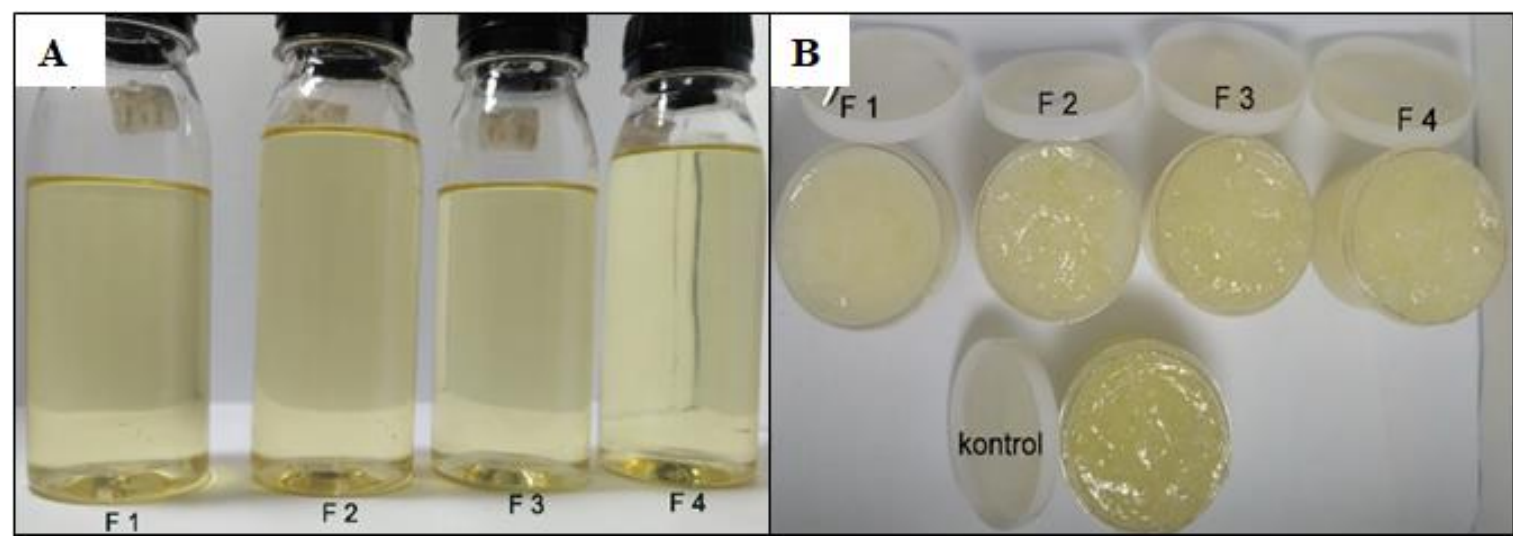

Gambar 1. Nanoemulsi Serbuk Lidah Buaya (a), Nanoemulgel Serbuk Lidah Buaya (b)

menunjukkan hasil yang jernih dengan nilai persen transmittan mendekati $100 \%$ seperti tercantum pada tabel. Semakin tinggi nilai persen transmittan (mendekati 100\%) maka nanoemulsi semakin jernih dan transparan yang merupakan salah satu parameter terbentuknya nanoemulsi (Mason et al., 2006). Pada formula 1, formula 2 , formula 3 dan formula 4 gambar 1(b) merupakan formula nanoemulgel yang berbeda konsentrasi gelling agent karbopol 940. Hasil pengukuran pada tabel 3 menunjukkan formula nanoemulsi memiliki distribusi ukuran partikel dibawah $100 \mathrm{~nm}$. Nanoemulsi masuk dalam range ukuran nano yaitu 1-100 nm (Singh et al., 2012).

Zeta potensial merupakan potensial permukaan atau muatan yang ada pada permukaan lapisan film nanoemulsi, yang menghasilkan gaya listrik diantara dropletdroplet minyak sehingga menghindari terjadinya koalesen.

Hasil pengukuran pada tabel 3 menunjukkan nilai zeta potensial yang sangat kecil yaitu $-0,1 \mathrm{mV}$. Nilai zeta potensial yang rendah disebabkan karena adanya surfaktan tween 80 yang merupakan surfaktan nonionik yang tidak bermuatan pada gugus hidrofobiknya, sehingga permukaan droplet minyak yang diselimuti oleh surfaktan ini cenderung tidak bermuatan (Wahyuningsih and Putranti, 2015). Nilai zeta potensial mendekati $\pm 30 \mathrm{mV}$ menunjukkan tingkat stabilitas nanoemulsi yang tinggi (Wang et al., 2006).

Pemeriksaan organoleptis sediaan nanoemulgel dilakukan dengan pengamatan terhadap konsistensi, bau, warna dan homogenitas dari tiap sediaan.

Hasil pemeriksaan organoleptis sediaan menunjukkan formula 4 memiliki konsistensi yang paling tinggi diikuti formula 3, formula 2 dan formula 1. Keempat formula nanoemulgel memiliki persamaan dalam bau (khas lidah buaya), warna jernih (kuning pucat) dan tingkat homogenitas sediaan. Perbedaan konsistensi dari keempat formula dipengaruhi oleh perbedaan konsentrasi gelling agent pada tiap formula, semakin tinggi konsentrasi gelling agent maka konsistensi sediaan semakin meningkat. Keempat formula memiliki homogenitas yang baik, yang ditandai dengan semua bahan tercampur merata.

Tabel 3. Hasil Uji Nilai Persen Transmittan, Distribusi Ukuran Pratikel dan Zeta Potensial Nanoemulsi

\begin{tabular}{cccc}
\hline & $\begin{array}{c}\text { Nilai Persen } \\
\text { Transmittan }(\%)\end{array}$ & $\begin{array}{c}\text { Distribusi Ukuran } \\
\text { Partikel }(\mathrm{nm})\end{array}$ & $\begin{array}{c}\text { Zeta Potensial } \\
(\mathrm{mV})\end{array}$ \\
\hline Nanoemulsi & $98,9 \pm 0,33$ & $65,05 \pm 13,49$ & $-0,1$ \\
\hline
\end{tabular}


Pengujian $\mathrm{pH}$ pada sediaan nanoemulgel bertujuan agar sediaan gel aman ketika digunakan pada kulit. Hasil pengujian menunjukkan formula 1 dan formula 2 memiliki pH 6, serta formula 3 dan formula 4 memiliki $\mathrm{pH}$ 5. Keempat formula nanoemulgel memiliki $\mathrm{pH}$ yang sesuai dengan rentang $\mathrm{pH}$ kulit yaitu 4,5-6,5 sehingga aman dan tidak mengiritasi kulit ketika digunakan (Tranggono and Latifah, 2007).

Uji daya lekat gel bertujuan untuk mengetahui kemampuan gel melekat pada kulit. Jika gel melekat terlalu kuat pada kulit maka akan menghalangi pori-pori kulit dan jika gel terlalu lemah melekat maka efek terapi tidak dapat tercapai (Hapsari et al., 2014). Seperti tercantum pada Gambar 2, daya lekat gel pada tiap formula terdapat perbedaan. Namun, berdasarkan analisa statistik perbedaan daya lekat tiap formula tidak signifikan yang ditunjukkan dengan nilai $p$-value sebesar $0,876(>0,05)$. Hal ini bermakna perbedaan konsentrasi karbopol pada tiap formula tidak memberikan perbedaan daya lekat. Daya lekat gel yang baik yaitu gel dapat melekat lebih dari 1 detik (Garg et al., 2002). Keempat formula memiliki daya lekat yang baik (>1 detik). Tidak terdapat perbedaan daya lekat pada keempat formula.

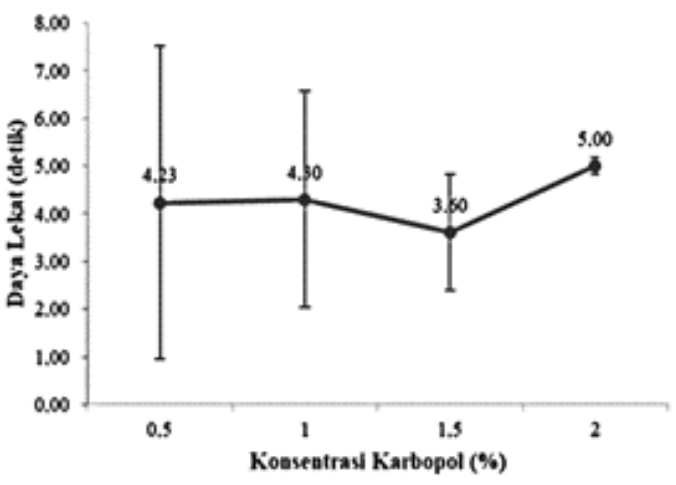

Gambar 2. Grafik Pengaruh Konsentrasi Karbopol terhadap Daya Lekat Gel

Uji viskositas gel bertujuan untuk mengetahui kekentalan dari gel. Gel yang baik memiliki kekentalan yang tidak terlalu kental dan tidak terlalu encer. Hal ini berhubungan dengan kemudahan penggunaan gel. Sediaan gel yang terlalu kental dapat menghambat pelepasan zat aktif. Tidak terdapat aturan khusus mengenai viskositas gel. Viskositas yang acceptable tidak berarti formula dengan viskositas paling tinggi atau paling rendah, tetapi formula yang memiliki daya sebar yang baik tergantung pada subjek uji (Garg et al., 2002). Pada gambar 3 dapat dilihat adanya perbedaan viskositas pada tiap formula. Hasil uji statistik menunjukkan hasil yang signifikan yang ditunjukkan dengan nilai $p$-value sebesar $0,015(<0,05)$. Hal ini menunjukkan adanya perbedaan konsentrasi karbopol pada tiap formula memberikan perbedaan viskositas. Semakin tinggi konsentrasi karbopol (gelling agent) yang digunakan maka akan meningkatkan viskositas sediaan. Formula 1 dengan konsentrasi karbopol $0,5 \%$ memiliki

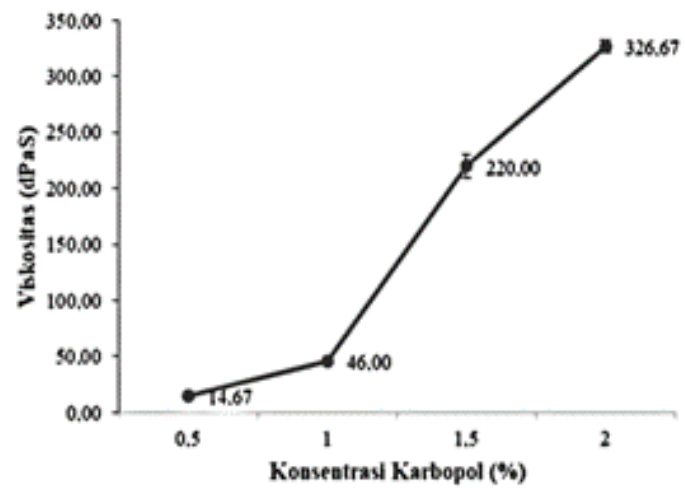

Gambar 3. Grafik Pengaruh Konsentrasi Karbopol terhadap Viskositas Gel

viskositas paling rendah dan formula 4 dengan konsentrasi karbopol 2\% memiliki viskositas paling tinggi.

Pengaruh konsentrasi kitosan yang digunakan sebagai gelling agent terhadap viskositas sediaan dapat diabaikan karena konsentrasi kitosan yang digunakan pada semua formula sama (konsentrasi kitosan tidak berpengaruh terhadap viskositas sediaan). Dapat dikatakan yang berpengaruh terhadap viskositas sediaan hanya konsentrasi karbopol pada tiap formula.

Uji daya sebar gel bertujuan untuk mengetahui kemampuan gel dalam menyebar ketika diaplikasikan pada kulit. Semakin 
besar daya sebar gel maka gel semakin mudah digunakan dan baik dalam melepaskan zat aktif. Tidak terdapat kriteria khusus mengenai daya sebar. Daya sebar berhubungan dengan viskositas. Daya sebar berbanding terbalik dengan rasio viskositas sediaan (Garg et al., 2002). Pada Gambar 4 terdapat perbedaan daya sebar antar formula.

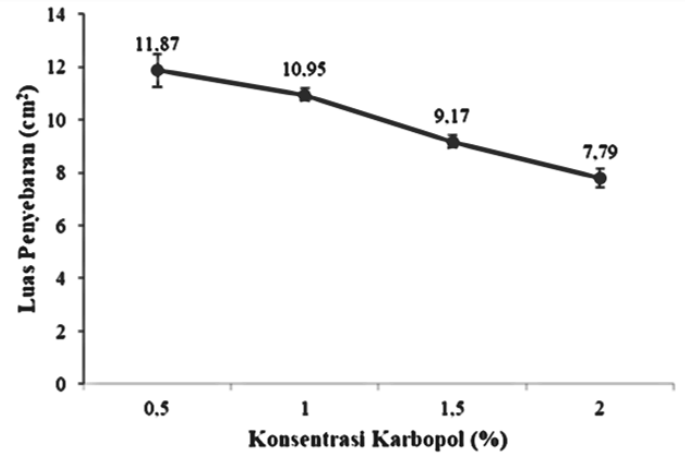

Gambar 4. Grafik Pengaruh Konsentrasi Karbopol terhadap Luas Penyebaran Gel

Hasil uji statistik menunjukkan hasil yang signifikan yang ditunjukkan dengan nilai p-value $0,000 \quad(<0,05)$, sehingga perbedaan konsentrasi karbopol pada tiap formula memberikan perbedaan daya sebar. Formula 1 memiliki daya sebar paling tinggi, diikuti formula 2, formula 3 dan formula 4 . Semakin meningkat konsentrasi karbopol (gelling agent) dalam gel maka daya sebar semakin menurun. Hal ini disebabkan semakin tinggi konsentrasi karbopol maka gel semakin kental (viskositas tinggi), sehingga gel semakin sukar menyebar.

Uji stabilitas fisik gel bertujuan untuk mengetahui kestabilan gel selama penyimpanan. Gel yang baik tidak mengalami perubahan selama penyimpanan. Pengamatan organoleptis gel selama 6 siklus freeze thaw menunjukkan tidak ada perubahan pada tingkat kosistensi gel, warna, bau dan homogenitas gel serta tidak terjadi pemisahan fase di dalam gel. Dapat dikatakan gel stabil secara organoleptis fisik. Pada pengujian $\mathrm{pH}$ gel selama 6 siklus freeze thaw juga tidak menunjukkan penurunan atau peningkatan $\mathrm{pH}, \mathrm{pH}$ tetap stabil. Penurunan $\mathrm{pH}$ pada gel dapat dipengaruhi oleh cahaya dan kelembaban. Pada gel yang menggunakan basis karbopol penurunan $\mathrm{pH}$ dapat terjadi karena reaksi antara gugus karboksilat pada karbopol dengan air sehingga terbentuk $\mathrm{H}_{3} \mathrm{O}^{+}$ (asam) yang semakin banyak sehingga membuat gel menjadi lebih asam (Sativa et al., 2014).

Pengujian daya lekat gel pada 6 siklus freeze thaw dapat dilihat pada gambar 5 .

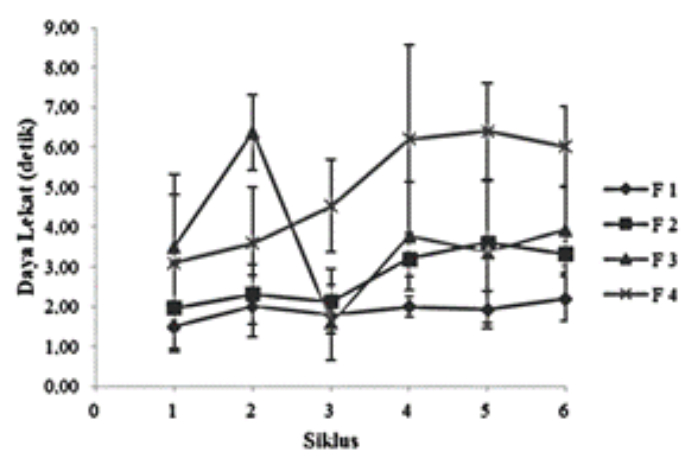

Gambar 5. Grafik Hubungan Lama Siklus Freeze Thaw dengan Daya Lekat Gel

Dari hasil analisa statistik menunjukkan penurunan daya lekat pada formula 2 dengan nilai signifikasi $0,044 \quad(p$-value $<0,05)$. Penurunan daya lekat yang signifikan juga terjadi pada formula 3 siklus ke-2 ke siklus ke-3 dengan nilai signifikansi sebesar 0,028 ( $p$-value $<0,05)$ dan pada siklus berikutnya terjadi kenaikan daya lekat. Secara umum hasil pengujian daya lekat gel menunjukkan hasil yang stabil kecuali formula 2 dan formula 3 .

Gambar 6 menunjukkan hasil uji stabilitas viskositas selama 6 siklus freeze thaw.

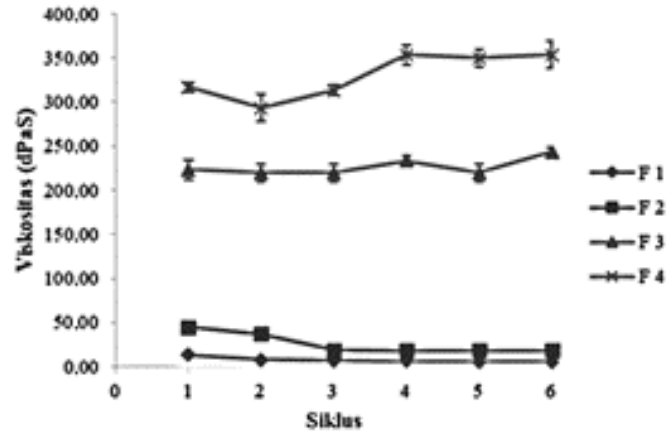

Gambar 6. Grafik Hubungan Lama Siklus Freeze Thaw dengan Viskositas Gel 
Penurunan viskositas terjadi pada formula 1 pada siklus ke-1 ke siklus ke-2 serta pada formula 2 pada siklus ke-2 ke siklus ke3 dengan nilai signifikansi $0,046 \quad(p$ value $<0,05)$. Pada formula 3 viskositas gel cenderung stabil yang ditunjukkan dengan nilai signifikasi ( $p$-value $>0,05)$ dengan membandingkan pada masing-masing siklus. Pada formula 4 terjadi peningkatan viskositas pada siklus ke-3 ke siklus ke-4 dengan nilai signifikansi 0,015 ( $p$-value $<0,05)$. Viskositas gel formula 1,2 dan 4 menunjukkan hasil yang tidak stabil karena terjadi penurunan viskositas secara signifikan pada sisklus tertentu Penurunan viskositas gel dapat terjadi karena penambahan kadar air yang terserap dari lingkungan dan juga perenggangan ikatan antar partikel pada suhu yang tinggi (Ramadhan, 2016).

Pengujian stabilitas daya sebar tercantum pada gambar 7 .

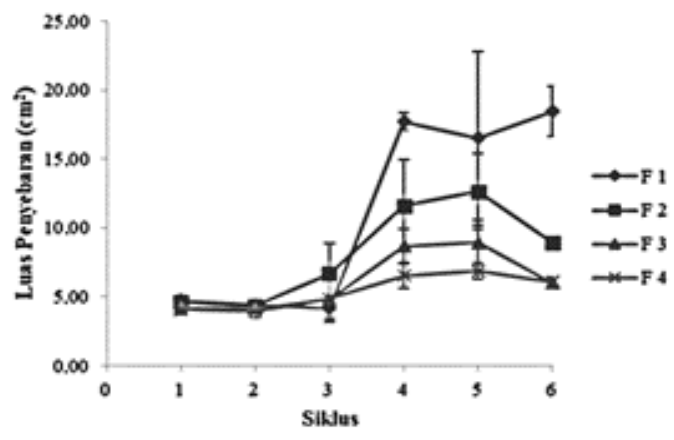

Gambar 7. Grafik Hubungan Lama Siklus Freeze Thaw dengan Luas Penyebaran Gel

Terjadi peningkatan luas penyebaran pada semua formula secara signifikan pada siklus ke-3 ke siklus ke-4 dengan nilai signifikansi ( $p$-value $<0,05)$. Peningkatan atau penurunan daya sebar gel dipengaruhi oleh viskositas gel, semakin tinggi viskositas gel maka semakin rendah daya sebar gel dan semakin rendah viskositas gel maka semakin besar daya sebar gel. Selain itu, daya sebar gel juga dipengaruhi oleh penggunaan alat yang tidak seragam. Ketidakseragaman alat uji daya sebar yang digunakan dapat memberikan hasil luas penyebaran yang berbeda-beda.

Secara keseluruhan formula 3 memiliki sifat fisik dan stabilitas fisik yang baik dibandingkan formula lainnya dengan melihat kestabilan viskositasnya selama penyimpanan karena akan berdampak pada stabilitas daya lekat dan daya sebar. Dengan sifat fisik yang baik maka sediaan gel diharapkan dapat memberikan efek terapi yang baik pula. Pada penelitian ini masih terdapat kekurangan, perlu dilakukan uji stabilitas fisik pada suhu ruang selama \pm 3 bulan agar diketahui stabilitas gel selama penyimpanan serta perlu dilakukan uji aktivitas baik secara in vitro maupun in vivo untuk mengetahui efektifitas terapi yang dihasilkan.

\section{KESIMPULAN}

Berdasarkan hasil penelitian yang telah di peroleh, dapat disimpulkan bahwa serbuk lidah buaya dapat diformulasikan sebagai sediaan nanoemulgel dengan ukuran droplet nanoemulsi $65,05 \pm 13,49 \mathrm{~nm}$; persen trasmittansi $98,9 \pm 0,33 \%$ dan zeta potensial 0,1 mV. Perbedaan konsentrasi karbopol 940 dan kitosan sebagai gelling agent pada tiap formula memberikan sifat fisik yang berbeda pada sifat fisik viskositas daya lekat dan daya sebar, namun tidak memberikan perbedaan organoleptis dan $\mathrm{pH}$. Perlu dilakukan uji aktivitas baik secara in vitro maupun in vivo untuk mengetahui efektifitas terapi yang dihasilkan.

\section{PERSANTUNAN}

Penulis mengucapkan terima kasih kepada Universitas Muhammadiyah Surakarta yang telah mendanai penelitian ini melalui hibah PID. 


\section{Daftar Pustaka}

Ahlam, 2011, Formulasi Sediaan Gel Ekstrak Lidah Buaya (Aloe vera L.) dengan Gelling Agent Kitosan dan Uji Efek Penyembuhan Luka Bakar, Naskah Publikasi, Universitas Muhammadiyah Surakarta.

Al-Fatimi M., Wurster M., Schröder G. and Lindequist U., 2007, Antioxidant, antimicrobial and cytotoxic activities of selected medicinal plants from Yemen, Journal of Ethnopharmacology, 111 (3), 657-666.

Arellano A., Santoyo S., Martín C. and Ygartua P., 1999, Influence of propylene glycol and isopropyl myristate on the in vitro percutaneous penetration of diclofenac sodium from carbopol gels, European Journal of Pharmaceutical Sciences, 129-135.

Azizah R.T., 2018, Uji Aktivitas Antibakteri Gel Serbuk Lidah Buaya (Aloe vera var.sinensis) Berbasis Carbopol 934 Terhadap Staphylococus aureus dan Pesudomonas aeruginosa, Naskah Publikasi, Universitas Muhammadiyah Surakarta.

Bashir A., Saeed B., Mujahid T.Y. and Jehan N., 2011, Comparative study of antimicrobial activities of Aloe vera extracts and antibiotics against isolates from skin infections, African Journal of Biotechnology, 10 (19), 3835-3840.

Christiawan A. and Perdanakusuma D., 2010, Aktivitas Antimikroba Daun Binahong Terhadap Pseudomonas aeruginosa dan Staphylococcus aureus yang sering menjadi Penyulit Pada Penyembuhan Luka Bakar, Jurnal Ilmu Bedah plastik, 1-6.

Elya B., Dewi R. and Budiman M.H., 2013, Antioxidant cream of Solanum lycopersicum L., International Journal of PharmTech Research, 5 (1), 233-238.

Furnawanthi I., 2002, Khasiat dan Manfaat Lidah Buaya, Agro Media Pustaka, Jakarta.

Garg A., Aggarwal D., Garg S. and Singla A.K., 2002, Spreading of semisolid formulations An Update, Pharmaceutical technology, www.pharmtech.com, 84-105.

Hapsari I., Rosyadi A. and Wahyuningrum R., 2014, Optimasi Kombinasi Minyak Atsiri Bunga Kenanga Dengan Herba Kemangi Dalam Gel Sebagai Repelan Nyamuk Aedes aegypti Dengan Metode Simplex Lattice Design, Prosiding Seminar Nasional dan Workshop "Perkembangan Terkini Sains Farmasi dan Klinik IV” tahun 2014, 31-37.

Kumar M.N.V.R., Muzzarelli R.A.A., Muzzarelli C., Sashiwa H. and Domb A.J., 2004, Chitosan chemistry and pharmaceutical perspectives, American Chemical Society, 104 (12), 6017-6084.

Mason T.G., Wilking J.N., Meleson K., Chang C.B. and Graves S.M., 2006, Nanoemulsions: Formation, structure, and physical properties, Journal of Physics Condensed Matter, 18 (41), 635-666.

Mou D., Chen H., Du D., Mao C., Wan J., Xu H. and Yang X., 2008, Hydrogel-thickened nanoemulsion system for topical delivery of lipophilic drugs, International Journal of Pharmaceutics, 353 (1-2), 270-276.

Prabaharan M. and Mano J.F., 2005, Chitosan-based particles as controlled drug delivery systems, Drug Delivery: Journal of Delivery and Targeting of Therapeutic Agents, 12 (1), $41-57$. 
Ramadhan F.A., 2016, Formulasi Sediaan Gel Nanoemulsi Ekstrak Kulit Buah Rambutan (Nephelium lappaceum L): Stabilitas Fisik dan Aktivitas Tabir Surya, Naskah Skripsi, Universitas Muhammadiyah Surakarta.

Sativa O., Yuliet and Sulastri E., 2014, Uji Aktivitas Antiinflamasi Gel Ekstrak Buah Kaktus (Opuntia elatior Mill.) Pada Tikus (Rattus norvegicus L.) Yang Diinduksi Lamda Karagenan, Online Journal of Natural Science, 3 (2), 79-94.

Singh B.P., Kumar B., Jain S.K. and Shafaat K., 2012, Development and characterization of a nanoemulsion gel formulation for transdermal delivery of carvedilol, International Journal of Drug Development and Research, 4 (1), 151-161.

Tranggono R.I. and Latifah F., 2007, Buku Pegangan Ilmu Pengetahuan Kosmetik, Djajadisastra, J., ed., PT. Gramedia, Jakarta.

Wahyuningsih I. and Putranti W., 2015, Optimasi Perbandingan Tween 80 dan Polietilenglikol 400 pada Formula Self Nanoemulsifying Drug Delivery System (SNEDDS) Minyak Biji Jinten Hitam, Pharmacy, 12 (02), 223-241.

Wang J.J., Sung K.C., Hu O.Y.P., Yeh C.H. and Fang J.Y., 2006, Submicron lipid emulsion as a drug delivery system for nalbuphine and its prodrugs, Journal of Controlled Release Elsevier, 115 (2), 140-149.

Widayanti A., Fauziah D.A. and R N.S., 2016, Formulasi Sediaan Gel Kolagen Ikan Tuna (Thunnus albacares) Dengan Hidroksipropil Metilselulosa (HPMC) Sebagai Gelling Agent, Farmasi sains, Universitas Muhammadiyah Prof. DR. Hamka, 3 (1), 1-6. 